\title{
Gender Digital Divide and Education in Latin America: A Literature Review
}

\author{
Ana Ancheta-Arrabal *(D), Cristina Pulido-Montes (D) and Víctor Carvajal-Mardones \\ Department of Comparative Education and History of Education, Faculty of Philosophy and Sciences of \\ Education, University of Valencia, 46010 Valencia, Spain; cristina.pulido@uv.es (C.P.-M.); \\ vicecar@alumni.uv.es (V.C.-M.) \\ * Correspondence: ana.ancheta@uv.es
}

check for updates

Citation: Ancheta-Arrabal, A.;

Pulido-Montes, C.; Carvajal-

Mardones, V. Gender Digital Divide and Education in Latin America: A

Literature Review. Educ. Sci. 2021, 11, 804. https://doi.org/10.3390/

educsci11120804

Academic Editor: Margus Pedaste

Received: 12 November 2021

Accepted: 3 December 2021

Published: 10 December 2021

Publisher's Note: MDPI stays neutral with regard to jurisdictional claims in published maps and institutional affiliations.

Copyright: (c) 2021 by the authors. Licensee MDPI, Basel, Switzerland. This article is an open access article distributed under the terms and conditions of the Creative Commons Attribution (CC BY) license (https:// creativecommons.org/licenses/by/ $4.0 /)$.

\begin{abstract}
Gender equity in education is one of the main targets for social justice and sustainable development. This literature review, from a gender approach, was conducted to understand how the gender digital divide (GDD) in information and communication technologies (ICT) and education are related in Latin American countries. A total of 28 articles have been analyzed as a satisfactory sample of the scientific literature to examine how this relation is explored and its influence, to acknowledge political stakeholders, as well as provide information and proposals to address the digital gender divide in education research in this region. The results show the need to develop research from the pedagogical and gender perspectives in Latin America, since they are not represented within an obvious problem.
\end{abstract}

Keywords: digital divide; digital gender divide; education; Latin America

\section{Introduction}

Worldwide, there is a large gap in women and girls' digital adoption and use compared to men and boys, even though most data available to quantify this gap focuses on adults only, not children [1]. Moreover, there is little research on gender differences in digital access for children under the age of 18 , but reasons for the digital gender gap include inequitable access to education and harmful social norms that exist in the "offline" world and impact digital realities and potential benefits for women and girls [2]. Inequality in education represents a major contributor to the gender digital divide, therefore women's and girls' digital adoption and use is frequently limited by lower levels of digital literacy, and a lack of confidence [3,4]. That can leave women and girls more vulnerable to online risks than men and boys [5]. More research and data are needed in order to effectively design programmes and initiatives that work to close the gender digital divide for girls.

The promotion of research on digital gender exclusion is a strong workspace in Spain, the UK, Canada and the US, but in Latin America the production is scarce, little cited and disjointed, as well as the global articulation of groups of discussion around the subject $[6,7]$. In fact, one of the findings in the research made at Universidade Estadual Paulista, which included the most cited literature in English, Spanish and Portuguese in the domain of the digital divide, was that Latin America does not research on the problems of digital divide related to gender and it highlights that the fact that the region is considered to have made notable progress in accessibility is one of the reasons why not enough studies have been carried out in the region on the digital divide [8,9]. Other author adds that the digital divide measurement model has been designed from the countries of the global North and that it is necessary to build a concept from the realities of the countries or regions of the Global South [10].

To add to this, the COVID-19 pandemic resulted in the disruption of on-site educational activity in most countries throughout the world during 2020. This led most 
governments to rely on communication technologies and information (ICT) to give continuity to the right to education during the months of school closure and confinement. Various researchers have shown how, in the international spectrum, many countries and entire regions have developed or implemented alternatives to online education to give continuity to the right to education, due to the lack of means, infrastructure and material and personal resources to support this educational path [11-13]. In this line of research on the right to education affected by the decisive political conditions for the control of the pandemic, studies from the gender perspective have been a minority, and they are in an incipient phase with respect to gender intersectionality [14-16].

Several authors have pointed out that the COVID-19 pandemic has affirmed the extant underlying inequalities in our society, and, furthermore, they have been accentuated in all spheres of people's lives, especially regarding education [17-19]. The digital gaps of access, use and quality and the digital gender gap have been accentuated, in global terms, during the pandemic and, above all, have had a greater impact on the most vulnerable groups [20-22].

In the case of Latin American women, a detailed study on the access and use of ICT during the pandemic has corroborated that the already dramatic situation of women in relation to the use of ICT in the region would have worsened as result of the COVID-19 [23]. This work relies on this evidence to study the digital gender divide in Latin America and, more specifically, on the digital gender divide and education from a pedagogical perspective in relation to this topic.

This article presents a study on the digital gender divide and education in Latin America. Specifically, it shows how these studies have been approached from the perspective of the digital divide itself in its three dimensions-access, use and quality-as well as the pedagogical approach of investigations. The research covered the period from January 2010 to May 2021, considering three academic databases. The initial search yielded 234 articles. After applying the exclusion criteria, 28 articles remained to be analyzed.

The content is divided into six sections. After Section 1, Section 2 addresses the basic concepts that lay out the background of this study. Section 3 defines the research methodology. Next, the article contains Section 4 dedicated to the results, mainly presenting the analysis approach from the digital divide and the digital gender divide and the pedagogical approach of the selected investigations. Section 5 contains a discussion of the results. Finally, Section 6 addresses final considerations and future work.

\section{Background}

This section presents realities and principles related to the digital divide, the digital gender divide in the Latin American context.

\subsection{Digital Divide}

Information and communication technologies (ICT) emerged at the end of the 1970s with the rise of information technology in most developed countries but, above all, with the expansion of the internet in the early 90s of the past century [24]. At this initial stage, there was an optimistic belief that it would be a tool for reducing inequalities [25]. However, the concept of the digital divide can be traced back to 1978 in a UNESCO report on the provision of infrastructure and computer support for the poorest countries to place them at the forefront of the richest [26]. Subsequently, with the irruption of the world wide web, the debates about the digital gap in access, understood as the physical or economic limitations to be able to have a connection to the network or ICTs, were intensifying [6]. From there on, policies in developing countries were aimed at providing infrastructures defined by computers and connection to the internet so that people could have access to them, for the purposes of inclusion [20]. This approach is associated with the policies carried out by national governments based on the material provision brought the associated idea that its continued use would lead to digital literacy processes which, in turn, would improve the 
development and the quality of life of people; especially, for those who have been defined as "digital natives" [27].

From this moment on, most developed countries tried to ensure access for the majority of the population towards the end of the 2000s, leading to a second wave of works that defined the digital gap concept with more complexity and provided other dimensions of analysis. The underlying motivation of these studies was the recognition that ICTs had not come to solve inequalities, but were embedded in already latent inequalities, and were correlated with them [28]. The dimensions that the digital divide concept adopts would be defined by the access and use made of ICTs, especially with regard to the use of the internet [20]. The International Communications Union would develop three terminological dimensions defined as [29]:

- the digital access gap-people who access and those who do not access ICT;

- the digital gap of use-level of skills and abilities of use of ICTs; and

- the quality of use gap-differences in use between users.

Other investigations have evaluated the digital divide from other categories that show the addition to this new wave of research for redefinition of the digital divide, but that integrate the new dimensions, such as the work carried out by [30]. This is through employment of the Information Wealth Index, which integrates the three dimensions of the digital gap, defined as internet access, skills to use the internet and the abilities to function in digital ecosystems that can be mediated or interfered with or by other sociodemographic characteristics that do not depend on the user [30].

From this approach, that the digital gap is redefined and it is categorized as secondorder [20], evidences from research conclude, in general lines, that long-term access and use of ICT are characterized by the same determinants of inequality that had already been prevalent in society, such as those related to income, education, skills, employment, geography, age and ethnicity and gender, among others [21].

Today, less than $50 \%$ of the population of the so-called Global South nations do not have internet access, compared with $90 \%$ in the most advanced regions or countries from the Global North [31], p. 2. Within the first-mentioned group of countries, Latin America represents the region that has advanced the most, since great efforts were made to provide internet access during the 2000s [9]. However, these macro data do not correspond with the reality of Latin American households that barely have access to broadband [31]. Moreover, it is considered one of the most unequal regions in the world, so the digital divide is accentuated by the pre-existing inequalities in the region itself. The authors of [9] highlight that the fact that the region is considered to have made notable progress in accessibility is one of the reasons why not enough studies have been carried out in the region on the digital divide. Other authors add that the digital divide measurement model has been designed from the countries of the global North and that it is necessary to build a concept from the realities of the countries or regions of the Global South [10].

\subsection{The Gender Digital Divide}

The first studies that related gender to technologies would begin in the 1980s in previous industrialized countries, due to the new analytical perspectives from a feminist approach [32]. Nevertheless, the expansion of studies on the Gender Digital Divide (GDD) began its journey and development as a result of the paradigmatic change in the matter of the approach of studies on the digital divide in its access and use. This is logical if we consider that, in an incipient stage of the research on the digital divide, the emphasis was placed on the fact that mere access already implied the integration of all sectors of the population, without attending to the multidimensionality of the concept of digital divides (access, use and quality) and the dependent variables or correlations with other latent inequalities in society [20].

However, it is relevant to note that studies that currently integrate the GDD in Latin America as their main object of analysis have been highlighted as insufficient compared 
with other geographies in more advanced countries, where this type of literature has proliferated $[8,33]$.

\subsection{Gender Digital Divide and Education}

There are several investigations highlighting that, to a large extent, education is one of the factors that intervenes in the use and access that girls, adolescents and women make of ICT $[1,34,35]$. Other research highlights that the different educational levels are predictors of the level of use and quality of the aforementioned ICT by population of the female gender and that, from this, the impacts that disable them to be able to develop in other contexts are derived [36]. Gender stereotypes, a horizontal gap when choosing studies or training in which women concentrate on careers typical of the social and human sciences, as well as the expectations of themselves in the use and capacities in an eminently masculine field are correlated with the GDD [6]. In this sense, studies have proliferated in the advanced countries that take into account GDD and training as part of the international policies developed by international organizations that have focused on training in STEM subjects (Sciences, Technologies, Engineering and Mathematics) to support the aforementioned gap [37].

Hence, the focus has been in how education or inequality in education represent a major contributor to the gender digital divide [1], but there is little attention to the digital inclusion of women in education, as well as to their training in digital competences and its impact in their opportunities of learning and future digital possibilities in this era of knowledge.

\section{Materials and Methods}

The methodology that was developed for this study was a review of the literature on the digital gender gap in education in Latin America from January 2010 to December 2021. The research for the studies was carried out through the following databases: Web of Science (https: / / www.webofscience.com/wos/woscc/basic-search) (accessed 9 October 2021), Scopus (https:/ / www.scopus.com/home) (accessed 9 October 2021) and SciELO (https://scielo.org/es/) (accessed 9 October 2021). The keywords entered in the metasearch engines of the referenced databases were the following: digital education gap, digital gender gap, digital gender gap and digital gender divide combined with the geographies under study. The following inclusion criteria (IC) allowed the following selection of articles: publication of full content (magazine articles and book chapters) on the digital gender divide or the digital divide in education, as well as those that, although they do not directly address the subject or object of research, at least contain gender bias in their results or integrate a gender perspective or approach in research, ranging from January 2010 to November 2021. The geographical context on which the search is applied is part of the ICs, that is, the region of Latin America on which research was carried out, correlating the keywords described with the name Latin America and Latin-America, as well as the correlation of these words with each of the countries that conform the region. To this end, it is relevant to notice that Table 2 only shows the geographies on which texts have been found that meet the following criteria. The exclusion criteria (EC) were determined by: publications prior to January 2010; summaries; doctoral theses; final degree projects; minutes of congresses or conferences; reviews; short essays and texts that use a language other than English or Spanish-except for research in Portuguese for the Brazilian context-as well as works outside this research and duplicate works. The volume of articles found in the Web of Science, Scopus and SciELO databases was a total of 234. Table 1 shows the representation of the studies according to the database and percentage of return articles, as well as the proportion of selected articles according to the IC: 
Table 1. Number of articles obtained by database and selected in the study.

\begin{tabular}{ccccc}
\hline Database & Return Articles & $\begin{array}{c}\text { Percentage } \\
\text { Return Articles }\end{array}$ & $\begin{array}{c}\text { Selected } \\
\text { Articles }\end{array}$ & $\begin{array}{c}\text { Percentage of } \\
\text { Selected Articles }\end{array}$ \\
\hline Scopus & 66 & $28.20 \%$ & 7 & $25 \%$ \\
SciELO & 55 & $23.50 \%$ & 9 & $32.15 \%$ \\
Web of Science & 113 & $48.30 \%$ & 12 & $42.85 \%$ \\
Total & 234 & $100 \%$ & 28 & $100 \%$ \\
\hline
\end{tabular}

Table 2 collects the information of studies according to the geographic context combined with the keyword and the language selected according to the IC.

Table 2. Number of selected articles according to geography, database and keyword.

\begin{tabular}{|c|c|c|c|c|}
\hline Geography & Language & Keywords & Databases & $\begin{array}{c}\text { Number of } \\
\text { Selected Articles }\end{array}$ \\
\hline \multirow{6}{*}{$\begin{array}{l}\text { Latina } \\
\text { America }\end{array}$} & Spanish & $\begin{array}{l}\text { Brecha Digital } \\
\text { Educación }\end{array}$ & Web of Science & 1 \\
\hline & \multirow{2}{*}{ English } & \multirow{2}{*}{ Digital Gender Gap } & Scopus & 1 \\
\hline & & & Web of Science & 3 \\
\hline & \multirow{3}{*}{ English } & \multirow{3}{*}{ Digital Gender Divide } & Scopus & 4 \\
\hline & & & Web of Science & 1 \\
\hline & & & SciELO & 1 \\
\hline \multirow{3}{*}{ Argentina } & \multirow{2}{*}{ Spanish } & \multirow{2}{*}{$\begin{array}{l}\text { Brecha Digital } \\
\text { Educación }\end{array}$} & Web of Science & 1 \\
\hline & & & SciELO & 1 \\
\hline & English & Digital Gender Gap & Scopus & 1 \\
\hline \multirow{2}{*}{ Brazil } & Spanish & $\begin{array}{l}\text { Brecha Digital } \\
\text { Educación }\end{array}$ & SciELO & 1 \\
\hline & English & Digital Gender Divide & Web of Science & 1 \\
\hline \multirow{3}{*}{ Chile } & Spanish & $\begin{array}{l}\text { Brecha Digital } \\
\text { Educación }\end{array}$ & SciELO & 1 \\
\hline & Spanish & Brecha Digital Género & Web of Science & 1 \\
\hline & English & Digital Gender Divide & Web of Science & 1 \\
\hline Colombia & Spanish & Brecha Digital Género & Scopus & 1 \\
\hline Costa Rica & Spanish & $\begin{array}{l}\text { Brecha Digital } \\
\text { Educación }\end{array}$ & SciELO & 1 \\
\hline \multirow[t]{2}{*}{ Ecuador } & Spanish & $\begin{array}{c}\text { Brecha Digital } \\
\text { Educación }\end{array}$ & Web of Science & 1 \\
\hline & English & Digital Gender Gap & Scielo & 1 \\
\hline \multirow{4}{*}{ México } & Spanish & $\begin{array}{l}\text { Brecha Digital } \\
\text { Educación }\end{array}$ & SciELO & 1 \\
\hline & \multirow{2}{*}{ English } & \multirow{2}{*}{ Digital Gender Gap } & Web of Science & 1 \\
\hline & & & SciELO & 1 \\
\hline & English & Digital Gender Divide & SciELO & 1 \\
\hline Uruguay & English & Digital Gender Gap & Web of Science & 1 \\
\hline
\end{tabular}

\section{Results}

This section presents the types of digital divide according to the approach adopted in the study, as well as the approach or the role given to education in it according to this literature review. Table 3 shows that research has used the digital divide on access in $28.57 \%$ 
as a framework for analysis, the digital divide on use in $71.43 \%$ and $100 \%$ of the studies mentioned or focused on education.

Table 3. Select articles on gender digital divide with the focus on ICT access.

\begin{tabular}{cc}
\hline Authors & Focus on Access to ICT \\
\hline Galperin \& Arcidiacono [31] & $\begin{array}{c}\text { Access to the internet at work improves the worker's ICT skills. } \\
\text { The access to information and assessment, as well as the } \\
\text { information exchange have come to the fore as an important } \\
\text { competence for people. }\end{array}$ \\
\hline Sánchez-Galvis [39] & $\begin{array}{r}\text { To increase women's access to information and communication } \\
\text { technologies (ICT), and so to increase their enjoyment of the } \\
\text { benefits derived from the information society. }\end{array}$ \\
\hline Botello-Peñaloza [40] & $\begin{array}{r}\text { Access and possession of devices for internet connection at } \\
\text { home depending on the socioeconomic income level. }\end{array}$ \\
\hline Suárez et al. [41] & $\begin{array}{r}\text { The map places us in specific economic conditions, in the face of } \\
\text { what is called "info-poverty", poverty of access. }\end{array}$ \\
\hline Martínez [42] & $\begin{array}{r}\text { Access to ICTs cannot be a solution to poverty but, in the best of } \\
\text { cases, it can be adopted as a tool for poverty } \\
\text { reduction initiatives. }\end{array}$ \\
\hline Domínguez et al. [43] & $\begin{array}{r}\text { The digital divide is related to differences in access to } \\
\text { computers in access and is related to income level, city area of } \\
\text { residence, age range and education. }\end{array}$ \\
\hline
\end{tabular}

As can be observed in Table 3, 28.57\% of the selected studies have carried out their research based on the approach focused from access to ICT, mainly mediated by access to the internet and a computer. Studies on access to ICTs are part of the first wave of centralized research on the digital divide starting in the late 1980s and early 1990s [20]. It is relevant that these studies are investigations dating from the second decade of the 2000s, where other digital gaps were considered-use and quality-but a reductionist approach has been advocated. In this sense, the studies collected here are empirical, descriptive or through surveys, so gender is seen as a predictive variable of the digital divide in global terms, but not as a phenomenon in itself or as a gap that is correlated with other existing gaps in society. These studies have their foundation on the need to adapt to the information and communication society marked by the status quo, and they are measured in terms of included or excluded, predominantly by income level or socioeconomic level. They follow an instrumental line on promoting access to employment and integration into the productive sphere, which can lead to a solution to get out of the circles of poverty or inequality. However, no critical studies with the ICT paradigm and its capitalist or male-dominated approach were founded; neither the possibilities that other types of studies which question the access-ICT-employability-development relationship can offer. Moreover, it should be noted that they are integrated into the studies categorized as optimistic about the possibilities of access and its impacts on the improvement of the rest of inequalities [44].

Table 4 shows that $71.43 \%$ of the studies analyzed have used analytical approaches typical of the second wave of research on the digital divide. These are more complex perspectives that take into account other gaps such as the access gap and the quality gap in use [20]. 
Table 4. Select articles on gender digital divide with the focus on ICT use.

\begin{tabular}{cc}
\hline Authors & Focus on Use of ICT \\
\hline Berrío-Zapata et al. [8] & $\begin{array}{c}\text { The lack of access to ICT makes its use impossible, which is linked to } \\
\text { a lack of access to education and employment. Lesser access and use } \\
\text { of ICTs by women lead to other types of exclusion. }\end{array}$ \\
\hline Bull [9] & $\begin{array}{c}\text { Existing inequalities or gender gaps and stereotypes mark less access } \\
\text { and use of ICTs in terms of gender due to the patriarchal model } \\
\text { of society. }\end{array}$ \\
\hline
\end{tabular}

\begin{tabular}{|c|c|}
\hline Aydin [38] & $\begin{array}{l}\text { "The capability of an individual to use computers to research, create, } \\
\text { and communicate in order to participate effectively at home, at } \\
\text { school, in the workplace, and in society" [45], p. } 17 .\end{array}$ \\
\hline Pérez-Escoda et al. [46] & $\begin{array}{c}\text { Access and use of the internet must be associated with the activities } \\
\text { that effectively generate positive externalities (broadening the } \\
\text { concept of community, expanding social connections beyond } \\
\text { geographical limits. }\end{array}$ \\
\hline Vega [47] & $\begin{array}{c}\text { Intensive use of both ICT and its knowledge, despite the existing } \\
\text { inequities, with a view to making decisions aimed at reducing the } \\
\text { gaps that hinder the ideal universalization of access to ICTs and } \\
\text { their use. }\end{array}$ \\
\hline Martínez [42] & $\begin{array}{l}\text { Meaningful use and accomplishment of the things with value to do or } \\
\text { be. As Björn-Söler Gigler [48], p. 34, states: “Access to information } \\
\text { and improved information skills act as improved literacy by } \\
\text { increasing people's ability to make decisions in their lives in various } \\
\text { areas, including economic, social and political spheres. }\end{array}$ \\
\hline Gray [44] & $\begin{array}{l}\text { Differences between men and women in the use of the internet to } \\
\text { identify a possible gender gap. }\end{array}$ \\
\hline $\begin{array}{l}\text { Barrantes and Vargas } \\
\qquad[30]\end{array}$ & $\begin{array}{l}\text { The Information Wealth Index (IWI) incorporates information on the } \\
\text { three barriers that restrict people to make significant use of the } \\
\text { Internet correlated with sociodemographic variables. }\end{array}$ \\
\hline $\begin{array}{l}\text { Marín-Raventós and } \\
\text { Calderón-Campos [34] }\end{array}$ & $\begin{array}{l}\text { The most difficult barrier to overcome is not related to access } \\
\text { (telecommunications infrastructure and artifact diffusion), but to use. } \\
\text { GGGI (Global Gender Gap Index): Participation, economic } \\
\text { opportunities, educational attainment, health, survival and political } \\
\text { empowerment. }\end{array}$ \\
\hline Trucco [35] & $\begin{array}{l}\text { Digital gaps between those who have the skills and abilities to benefit } \\
\text { from computer use and those who do not, closely linked to economic, } \\
\text { cultural and social capital. }\end{array}$ \\
\hline Hilbert [21] & $\begin{array}{l}\text { Digital divide defined by the inequality in the power to communicate } \\
\text { and process information digitally. GDD: differences between men's } \\
\text { and women's access to ICTs and their use. }\end{array}$ \\
\hline Montiel et al. [49] & $\begin{array}{l}\text { ICT as reproducers of different inequalities. An analysis is not made } \\
\text { of access or use, but of ICT as part of the capitalist tools that } \\
\text { reproduce inequalities and reinforce the gender gap. }\end{array}$ \\
\hline Berrío-Zapata et al. [6] & $\begin{array}{l}\text { Digital inclusion model that encompasses four types of access: } \\
\text { motivational, material, skills, and use. }\end{array}$ \\
\hline Delfino et al. [50] & $\begin{array}{c}\text { Model of access and use in which four types of access are considered: } \\
\text { motivational, material, skills and use. }\end{array}$ \\
\hline Benítez-Larghi [51] & $\begin{array}{l}\text { The reduction of the digital divide (device ownership and } \\
\text { connection) and transformation of the forms of teaching and learning } \\
\text { based on the use of ICT. }\end{array}$ \\
\hline $\begin{array}{c}\text { Meneses-Cabrera \& } \\
\text { Aranda-Bustamante [33] }\end{array}$ & $\begin{array}{l}\text { Measure the GDD by taking into account the voices of women in } \\
\text { relation to capacities and types of use that they have made of ICT to } \\
\text { know the realities that they represent. }\end{array}$ \\
\hline
\end{tabular}


Table 4. Cont.

\begin{tabular}{cc}
\hline Authors & Focus on Use of ICT \\
\hline Tareq Rashid [10] & $\begin{array}{r}\text { Digital inclusion: transcending mere physical access by considering } \\
\text { the broader social factors that impact women. }\end{array}$ \\
\hline $\begin{array}{c}\text { Yansen y Zukerferld [52] } \\
\text { Jonze of ICT that is linked to access to employment with ICT and } \\
\text { Jiménez \& } \\
\text { Jiménez-Fernández [36] } \\
\text { considers GDD and its link to horizontal segregation and } \\
\text { employability in the cyber sector and programming industry. }\end{array}$ & $\begin{array}{c}\text { Men create and manage digital innovation and women are the users } \\
\text { (access) of these innovations, and so the risk of increasing the gender } \\
\text { gap persists. }\end{array}$ \\
\hline Ruíz [53] & $\begin{array}{c}\text { The universalist claims that use and quality derive from access to ICT } \\
\text { do not consider the digital divide derived from other factors such as } \\
\text { the age, socioeconomic level, gender, etc. }\end{array}$ \\
\hline Gray et al. [44] & $\begin{array}{r}\text { Inclusion: access does not in itself ensure quality use that has other } \\
\text { impacts on development and has a gender component. }\end{array}$ \\
\hline
\end{tabular}

However, as can be seen in Table 4, studies carried out by other authors have been developed from the approach of the inclusion model that covers four types of access: motivational, material, skills, and use $[6,8,44,50]$. These analyses integrate issues such as gender, age, ethnicity, socioeconomic level or educational level that correlate with the aforementioned contextualization in access. Another research effort has applied the Information Wealth Index (IWI), which incorporates information on the three barriers that restrict people to make meaningful use (access, use and quality) of the Internet correlated with sociodemographic variables [30]. In all these studies, either the focus or the gender bias appears, since they are located in the second generation of analysis; that is to say, from the second-order digital divide or from the perspectives of inclusion and the threedimensional division of the digital divide $[20,21]$ that integrate the gender component as a sociodemographic element or dependent variable. Other investigations have directly addressed the issue of the digital gender gap from the perspective of second-generation studies on the digital gap $[6,8,9,21,33,34,36,52]$. Lastly, it is worth mentioning that other studies can be placed within a poststructuralist and critical approach that invites reflection on the masculine within the sciences of the computing and cybernetics, as well as how to rethink and demystify the concept of the digital gender gap [9,33,51].

Lastly, a compilation of articles that have handled with the gender digital divide throughout their research can be found in Table 5 .

Table 5. Selected articles on gender digital divide and education in the research.

\begin{tabular}{cc}
\hline Authors & Focus on Education \\
\hline $\begin{array}{c}\text { Berrío-Zapata et al. [8] } \\
\text { Meneses-Cabrera \& } \\
\text { Aranda-Bustamante [33] }\end{array}$ & $\begin{array}{c}\text { Interaction with cellular technology is also strongly associated with } \\
\text { education level and socioeconomic status, indirectly affecting women } \\
\text { in their technological capital. } \\
\text { gap, but rather it is pointed out as another exclusion that } \\
\text { women experience. }\end{array}$ \\
\hline $\begin{array}{c}\text { Galperin \& } \\
\text { Arcidiacono [31] }\end{array}$ & $\begin{array}{c}\text { Education is conceived as a predictor of internet use. They centralize } \\
\text { the improvement in the use of the internet by women derived from } \\
\text { their integration into employment. }\end{array}$ \\
\hline Bull [9] & $\begin{array}{c}\text { Education is a variable to control in studies on the digital gender gap } \\
\text { because it is correlated with internet use. The study proposes } \\
\text { non-formal educational routes such as: libraries and training courses } \\
\text { aimed at women for the use of ICT. }\end{array}$ \\
\hline
\end{tabular}


Table 5. Cont.

\begin{tabular}{cc}
\hline Authors & Focus on Education \\
\hline Barrantes \& Vargas [30] & $\begin{array}{c}\text { Education as an element for improving access and use of ICT by } \\
\text { women. It proposes open educational resources and learning } \\
\text { communities in educational centres. }\end{array}$ \\
\hline Gray et al. [44] & $\begin{array}{c}\text { Digital literacy, courses, conferences, and policy efforts targeting } \\
\text { women to reduce the digital gender gap that impacts other areas } \\
\text { of society. }\end{array}$ \\
\hline $\begin{array}{c}\text { Marín-Raventós \& } \\
\text { Calderón-Campos [34] }\end{array}$ & $\begin{array}{c}\text { Improve access to education by promoting initiatives that seek to } \\
\text { promote ICT training in secondary education aimed at girls } \\
\text { and adolescents. }\end{array}$ \\
\hline Trucco [35] & $\begin{array}{c}\text { A quality education improves equity in other dimensions of the } \\
\text { system. To keep and continue promoting centralized policies in } \\
\text { public education, in order to improve the use of ICT by adolescents. }\end{array}$ \\
\hline Hilbert [21] & $\begin{array}{c}\text { Lack of education negatively affects access and use of ICT. Accessing } \\
\text { and using ICT also means an improvement in education. }\end{array}$ \\
\hline Montiel [49] & Education produces and reproduces stereotypes in the use of ICT. \\
\hline Berrío-Zapata et al. [6] & $\begin{array}{c}\text { Education crossed by stereotypes and preconceptions that promote } \\
\text { DGG. Criticize technological education and the vertical and } \\
\text { horizontal segregation derived from education. }\end{array}$ \\
\hline
\end{tabular}

\begin{tabular}{c}
\hline Delfino et al. [50] \\
Benítez-Larghi [51] \\
\hline $\begin{array}{c}\text { González-Palencia } \\
\text { Jiménez \& }\end{array}$ \\
Jiménez-Fernández [36]
\end{tabular}

The different educational levels mark the quality of use of social networks and ICT.

Integrating ICT, teacher training and reflection on their integration in the classroom improves the quality of use that students make of them.

GDD marked by educational issues: horizontal and vertical gap, stereotypes, hidden curriculum. They recommend ways of formal education, teacher training in gender perspective, as well as in the non-formal education.

\begin{tabular}{|c|c|}
\hline Tareq Rashid [10] & $\begin{array}{l}\text { Tertiary education and the use of ICT at home as variables that } \\
\text { explain digital divides. }\end{array}$ \\
\hline Ruíz [53] & $\begin{array}{l}\text { Use of ICT in young people in secondary education. It proposes to } \\
\text { value and merge formal and informal education. }\end{array}$ \\
\hline Sánchez-Galvis [39] & $\begin{array}{l}\text { It correlates the differences in the use of ICT in relation to } \\
\text { educational level. }\end{array}$ \\
\hline Aydin [38] & $\begin{array}{l}\text { Knowledge, data literacy, creation of digital content, communication, } \\
\text { and collaboration skills as basic digital skills to be acquired by } \\
\text { students of the 21st century [54]. }\end{array}$ \\
\hline Pérez-Escoda et al. [46] & $\begin{array}{l}\text { A greater focus on teacher training is necessary to achieve a } \\
\text { transformation of their educational practice through a true } \\
\text { digitization of citizenship to achieve inclusive education }[55,56] \text {. } \\
\text { Review of the main aspects that influence gender bias in science and } \\
\text { technology especially, supported by a sexist education that can } \\
\text { perpetuate discriminatory stereotypes towards women. }\end{array}$ \\
\hline Vega [47] & $\begin{array}{l}\text { Continuous teacher training as an unavoidable requirement, to } \\
\text { "create and/or use technologies taking into account specific } \\
\text { pedagogical designs; identify and select the most appropriate } \\
\text { technologies for a specifically pedagogical design; and above all to } \\
\text { understand and understand what changes in education when new } \\
\text { technologies are used" [57], p. 56. }\end{array}$ \\
\hline Botello-Peñaloza [40] & $\begin{array}{l}\text { Higher educational level, greater use of the possibilities of ICT. } \\
\text { Production of positive externalities associated with the globalization } \\
\text { of knowledge and activities that can be carried out digitally. }\end{array}$ \\
\hline
\end{tabular}


Table 5. Cont.

\begin{tabular}{cc}
\hline Authors & Focus on Education \\
\hline Plascencia [58] & $\begin{array}{c}\text { Although the Internet can be a catalyst for social development, this } \\
\text { only occurs when the person has developed other cognitive skills, } \\
\text { such as those related to writing and reading comprehension. }\end{array}$ \\
\hline González et al. [59] & $\begin{array}{c}\text { Level of education as a predictor of inequalities in the use of ICT. } \\
\text { Domínguez et al. [44] }\end{array}$ \\
$\begin{array}{c}\text { Women could achieve better results by reducing this gap if they are } \\
\text { more promoted, starting from their families, allowing them to access } \\
\text { higher levels of education and employment, breaking cultural } \\
\text { barriers, such as machismo and domination, improving their } \\
\text { conditions of employment life. }\end{array}$ \\
\hline Dodel \& Aguirre [60] & $\begin{array}{l}\text { The higher the income and the higher the educational level, the } \\
\text { greater the possibilities of participation in the information and } \\
\text { communication society. }\end{array}$ \\
\hline
\end{tabular}

One of the approaches related to the gender digital divide that emerges from Table 5 is the one that correlates with levels of education and socioeconomic status [8]. In fact, the lack of education negatively affects the access and use of ICT [21]. Hence, there is a great consensus on education as an element for improvement in terms of access and use of ICT, and that quality education improves equity in other dimensions of the system $[30,35,39]$. In addition, public education and its access implies an improvement in terms of reducing the GDD, which is relevant since education appears as the element that produces and reproduces stereotypes in the use of ICT [49]. Therefore, it is stated that biased education by stereotypes and preconceptions encourages GDD [6]. That is why it becomes crucial to review scholarship on technological education and vertical and horizontal segregation as a result of education.

Some of the alternatives aim to overcoming these reproductive stereotypes of gender inequality [34]. Other initiatives focus as well on the improvement of access to education by promoting ICT training in secondary education aimed at girls and adolescents; in addition to digital literacy, courses, conferences, and efforts in policies aimed at women to reduce GDD [44]. The rest of measures that should be considered are framed in non-formal educational pathways, such as libraries and training courses aimed at women for the use of ICT $[9,26]$. In addition, the formal education channels, teacher training in gender perspective and in the non-formal must be considered.

From another perspective more linked to the labour market and employability, it is argued that the higher the income and the higher the educational level, the greater the possibilities of participation in the information and communication society [60]. In this same line, it is proposed continuous teacher training as an unavoidable requirement [49]; especially to "create and/or use technologies taking into account specific pedagogical designs; identify and select the most appropriate technologies for a pedagogical design; and, above all, to understand what changes in education when new technologies are used" [57], p.56. Finally, education is outlined as a predictor of the internet use, centralizing the improvement in use by women derived from their integration into employment [31]. In this hypothesis women could achieve better results if they were more promoted, beginning within the family, by allowing them to access higher levels of education and employment, and breaking cultural barriers, such as machismo and domination or by improving their living conditions [43].

Continuing with the analysis of Table 5 , it is relevant to highlight a basic requirement to overcoming digital divides in education, in which it is proposed that even the internet can be a catalyst for social development, and this only occurs when the person has developed other cognitive skills, such as those related to writing and reading comprehension [58]. In this sense, the knowledge, literacy, creation of digital content, communication and collaboration skills are considered as basic digital skills to be acquired by students of the 21st century $[31,38,39]$. Additionally, it is reinforced the idea that a greater teacher 
training could achieve a transformation of educational practice through a true digitization of citizenship, achieving an inclusive education $[55,56]$. They do so by considering the review of the main aspects that influence gender bias in science and technology, especially supported by a sexist education that can perpetuate discriminatory stereotypes for women.

Finally, as [61] pointed out, it is important that we ask ourselves, who has to close this new gap in education or at least keep it as limited as possible? The answer is given to us by these same authors "As long as another institution is not invented, and it does not seem that it is possible or necessary to do so for now, it is time to close it to the school" [61], p. 50.

\section{Discussion}

This section presents the results obtained by reviewing the literature, analyzing the articles, and identifying gaps to promote future research. The analysis of the 28 articles studied reflected how $28.57 \%$ were developed from the approach of access to ICT, as an element that will lead to the reduction of the digital divide, compared to $71.43 \%$ who apply other models that consider other gaps (use and access) to understand the phenomenon of the digital divide.

Regarding the articles' categorization, in which the approach from the access to ICT (internet and computers) as an element that emerges from the reduction of the digital divide, it has been possible to observe an instrumental relationship that does not attend to either of the negative correlations derived from socioeconomic and sociodemographic variables. These studies are based on a market rationale, in which access results in positive impacts on the integration into the labor market or as an opportunity to develop lifelong learning. These studies have been defined in [44] as part of the optimism in access. Therefore, these studies do not integrate a gender perspective or an approach based on the GDD and, if categorizations are established in relation to sex, they are part of the nature of the research (empirically based on surveys). As a differential note, it should be reported that studies that integrate the gender perspective in their analyses began to be developed in the 1990s and the recontextualization of the digital divide, which considered it in terms of access, use and quality [20]. Even so, these studies carried out in the Latin American region do not implement more complex approaches in their analyses. In this respect, the hypotheses of many of the investigations here reviewed, materializes the observation that studies with a gender perspective in the region are insufficient and this obtains from reasons or a rationale based in the assumption that there is not such a problem, because access to ICTs have been widely ensured since the 2000s $[6,8,9,21,33]$. The aforementioned authors agree that assuming the extension of access in the region to be homogeneous is an error, as it is one of the most unequal regions of the world and in which there are broad gender stereotypes that are not addressed by national government institutions because they hold, within them, a patriarchal bias.

Concerning the categorization of the analyzed studies according to the three-dimensional approach to the digital divide on access, use and quality [29], 71.43\% of the investigations (as previously collected) deal with studies that have implemented this type of methodology. It is pertinent to make visible that not all these studies have conceptualized the digital gender gap in the corpus of their research, but the analysis approach, itself, from the three gaps that consider sociodemographic and socio-economic variables, integrate gender as a variable to take into consideration. This has resulted in studies that contemplate the reality of women in an eminently masculine and masculinized field, such as cybernetic and computer sciences, making it possible to make visible problems derived from vertical, horizontal and motivational segregation in access to ICT. It is from these investigations that the realities suffered by women in the region are problematized, as well as how this derives or correlates with other inequalities that reduce the possibilities of women to develop, at all levels, in the society of communication and information $[6,8,10,30,34,35,38,39,42,44,47,50-53]$.

Other studies, but a minority in this literature review, have rendered their analyses from a critical, hermeneutical or poststructuralist approach. This means that they attend to digital divides from a perspective that emphasizes the dominance of the masculine in 
the field of cybernetics and in capitalist instrumentality, so, too, the centrality endowed to the information and communication society, and they advocate building research from hermeneutical and discursive positions in order to question the use of these types of concepts and their roles in the reproduction and production of gender inequalities $[9,36,49]$. This last set of research problematizes the reality of women in Latin America and proposes carrying out intersectional studies that consider the digital divide as "digital divides" in an unequal region and where gender inequality is one of the realities that are problematizing the coexistence and the possibilities of women.

However, from a pedagogical approach, the results obtained allow establishing a broad discussion about the purposes of education and the instrumentalization that is carried out of the pedagogical in the field of ICT. It is, above all, those studies from the perspective of the triple-dimensional digital divide that consider education as a variable dependent on the digital divide and the digital gender divide. Most of these texts conclude with the idea that, with higher educational levels, there are greater possibilities of narrowing the digital divide and of being able to take advantage of the opportunities that lead to good and quality use of ICT in other contexts.

The initial purpose of this research was to collect the studies that were being carried out on the digital gender divide in education in Latin America-curiously, in the end, since no works have been found that address the issue from the understanding of education as an aim in the digital gender gap. In this way, education is one of the stand-out inequalities derived from the motivational gap; that is, from the dispositions of girls and adolescents to decide on the study of computer science. Horizontal, vertical segregations and stereotypes are addressed as a problematic issue that is conditioning of the GDD, which occurs within the school institution and homes [6,8,49]. The social problematization in relation to the gender gaps attributed in these studies end up by pointing to educational institutions, since they are part of society. The adjectivization of education is, once again, emphasized; that is, to exploit its pedagogical function of reducing inequalities in the catalytic idea thereof and it is identified as a tool to combat or reduce the gender gap [62]. However, in itself, the aims of education are not discussed, and an instrumental vision associated with human capital is offered through solutions that are integrated into the background of the articles. In fact, these are presented as part of the political recommendations that can be carried out to reduce the digital gender gap, based on courses, seminars, conferences, learning communities, promotion of STEM subjects in education, etc., but the substance of/means by which education can be the producer or reproducer of these inequalities is not discussed, in line with [49].

\section{Conclusions and Future Research}

Studies on the impact of ICTs on the digital gender divide in Latin America are insufficient and are not addressed from a pedagogical approach- This is even though the described causes in research on access, use and quality for the development of women in the communication and information society mostly point to factors associated with gender stereotypes and the expectations of girls, women and adolescents regarding ICTs. The main objective of this literature review was to address the digital gender gap in education in Latin America, but it has been determined by the nature and focus of the literature that it does not specifically address this issue and its pedagogical approach. In the texts, the relation of competences is referred to as one of the limitations in the use and quality of ICT, but the educational approach loses strength or is predetermined as an element that cannot be dispensed for the development of a research that addresses the digital divide.

Furthermore, the main conclusion is that research on the gender digital divide in education in America Latina is scarce and is approached from other areas of knowledge, but not from education, as has been verified in this research. This shows how this issue is not specific to the GDD issue, but also belongs, in general, to the research in the region on the digital divide and its relationship with education. In this sense, a deep reflection is essential to establish a consistent theoretical framework to support future research 
that focuses its object of study on the digital divide of the education subjects, processes and educational contexts themselves, from a pedagogical approach. This implies the inclusion of the emerging pedagogies approach, which is defined in [63] as a "set of pedagogical approaches and ideas, not yet well systematized, that arise around the use of ICT in education and that try to take advantage of all their communicative, informational, collaborative, interactive, creative and innovative potential within the framework of a new learning culture, p.15. Especially, in relation to its importance in avoiding gender bias in deep learning processes and, at the same time, in providing women with the means to become digital creators [64].

Therefore, the GDD in education is a central issue and a necessary context of approach if we consider the impacts of COVID-19 on education and the educational crisis in the region. Digital gaps have increased even more, if possible, after the COVID-19 pandemic [22]. Considering the situation of school closures in Latin America, it is possible to assume that girls, adolescents and women are exposed to a greater risk of facing various forms of digital exclusion.

These gender-differentiated impacts aggravate situations of vulnerability and the impairment of rights that women and girls in Latin America have already experienced. This context, in turn, determines their possibilities for participation in the alternative learning modalities implemented by many countries in the region. In this sense, the deployment of responses based on exhaustive gender analysis is essential for guaranteeing the participation of women and girls in their design, implementation, monitoring and evaluation. Inequality in access to educational opportunities through digital means increases the preexisting gender gaps in access to information and knowledge, which, beyond the learning process that is being promoted through distance education, makes difficult socialization and inclusion in general. It is necessary to understand these gaps from a multidimensional perspective, because it is not only a difference in access to equipment, but also the set of skills that are required to take advantage of it as opportunity, which is unequal among students, teachers and family members in charge of the care and mediation of this learning process, which, today, takes place at home [65]. Preparing, in the medium and long terms, to reduce the digital divide in this deeper sense sets in motion virtuous synergies of social and cultural inclusion for children and adolescents, generating opportunities for life and to face future crises [66].

ICT use determines people's professional and vital development. This makes digital gender exclusion a serious problem, affecting half of humanity - women-without a clear awareness of it. Research in this context provides information for the female community to become aware and act as an organized minority towards the status quo. The limitations of research on the gender digital divide in Latin America reflect general problems of a lack of depth and detail about the various and subtle aspects of this phenomenon.

In this respect, according to [1], the factors that need to be addressed to close the gender digital divide can be broadly categorized into three interlinked areas: access, digital literacy and online safety. For them, more research and data are needed in order to effectively design programmes and initiatives that work to close the gender digital divide for girls (for example, country or regional demand-side surveys that focus on adolescents under the age of 18, or by integrating sex-disaggregated data on digital adoption for adolescents into regular national surveys, or by exploring innovative approaches to data and insights, such as big data); context-specific research is also needed to understand girls' digital experiences, the security and safety risks they may face online, and any issues and fears in their communities about girls' use of technology.

As a general conclusion after these reviews, we propose that gender is implicit in the digital divide. Therefore, studies on the digital divide should be developed addressing gender issues not as something to be avoided, but rather that form part of the exact definition and the work methodology that address the aforementioned reality. It is worth mentioning studies, such as $[67,68]$, from a comparative perspective between Latin America 
and the Caribbean and the European Union, using an approach that takes into account the digital divide, integrating gender as a dependent variable.

In any case, without doubting the extraordinary capacity of digital intelligence to transform each social sector in a positive sense, such as education, it is nevertheless necessary to address the imbalances that its unregulated use can create in this region [69].

Author Contributions: Conceptualization, A.A.-A. and V.C.-M.; methodology, C.P.-M. and V.C.-M.; software, C.P.-M.; validation, A.A.-A., C.P.-M. and V.C.-M.; formal analysis, C.P.-M.; investigation, A.A.-A.; resources, A.A.-A. and C.P.-M.; data curation, A.A.-A., C.P.-M. and V.C.-M.; writing-original draft preparation, A.A.-A., C.P.-M. and V.C.-M.; writing-review and editing, A.A.-A.; visualization, C.P.-M. and V.C.-M.; supervision, A.A.-A. and C.P.-M.; project administration, A.A.-A., C.P.-M. and V.C.-M.; funding acquisition, A.A.-A. and C.P.-M. All authors have read and agreed to the published version of the manuscript.

Funding: Department of Comparative Education and History of Education, University of Valencia.

Conflicts of Interest: The authors declare no conflict of interest.

\section{References}

1. Tyers-Chowdhury, A.; Binder, G. What We Know about the Gender Digital Divide for Girls: A Literature Review. UNICEF Gender and Innovation Evidence Briefs-Insights into the Gender Digital Divide for Girls. 2021. Available online: https:/ / www.unicef.org/eap/media/8311/file/What\%20we\%20know \%20about\%20the\%20gender\%20digital\%20 divide\%20for\%20girls:\%20A\%20literature\%20review.pdf (accessed on 5 October 2021).

2. Tyers, A.; Global, B. USAID Gender Digital Divide Desk Review Report. 2020. Available online: https:/ /www.marketlinks.org/ weege-wiki/gdd-desk-review-report (accessed on 5 October 2021).

3. EQUALS. Taking Stock: Data and Evidence on Gender Equality in Digital Access, Skills, and Leadership. 2019. Available online: https:/ / www.itu.int/en/action/gender-equality/Documents/EQUALS\%20Research\%20Report\%202019.pdf (accessed on 12 October 2021).

4. GSMA Connected Women. The Mobile Gender Gap Report 2020. 2020. Available online: https://www.gsma.com/ (accessed on 10 September 2021).

5. EIGE. Gender Equality and Youth: Opportunities and Risks of Digitalisation. 2019. Available online: https://eige.europa.eu/ publications / gender-equalityand-youth-opportunities-andrisks-digitalisation (accessed on 10 September 2021).

6. Berrío-Zapata, C.; Arraiza, M.P.; da Silva, F.E.; das Chagas, S.E. Desafíos de La Inclusión Digital: Antecedentes, Problemáticas y Medición de La Brecha Digital de Género. Psc. Piscología Conoc. Soc. 2017, 7, 162-198. [CrossRef]

7. Berrío-Zapata, C.; Sant'Ana, G.R.C. Exclusión Digital: Discurso y Poder Sobre La Tecnología de La Información; Editorial Unesp: Sao Paulo, Brasil, 2017.

8. Berrío-Zapata, C.; Ferreira da Silva, E.; Brandão Guarald, T.; Grossi-de-Carvalho, A.M. Exclusión digital de género: Rompiendo el silencio en la ciencia de la información. Rev. Interam. Bibl. 2020, 43, 130-143. [CrossRef]

9. Bull, L. De-myth-tifying the Gender Digital Divide in Latin America: Libraries as Intermediaries in Bridging the Gap. DJIM. Dalhous. J. Interdiscip. Manag. 2016, 12. [CrossRef]

10. Tareq Rashid, A. Digital Inclusion and Social Inequality: Gender Differences in ICT Access and Use in Five Developing Countries. Gend. Technol. Dev. 2016, 20, 306-332. [CrossRef]

11. Dreesen, T.; Akseer, S.; Brossard, M.; Dewan, P.; Giraldo, J.P.; Kamei, A.; Mizunoya, S.; Santiago, J.; Correa, O. Promising Practices for Equitable Remote Learning Emerging Lessons from COVID-19 Education Responses in 127 Countries; UNICEF: New York, NY, USA, 2020 .

12. Lorente, L.M.L.; Ancheta-Arrabal, A.; Pulido-Montes, C. The Right to Education and ICT during COVID-19: An International Perspective. Sustainability 2020, 12, 9091. [CrossRef]

13. Martínez-Dominguez, M.; Fierros-González, I. Determinants of internet use by school-age children: The challenges for Mexico during the COVID-19 pandemic. Telecommun. Policy 2021, 2021, 102241. [CrossRef]

14. Murillo, F.J.; Duk, C. El COVID-19 y las Brechas Educativas. Rev. Latinoam. Educ. Inclusiva 2020, 14, 11-13. [CrossRef]

15. Navarro Cejas, M.; Delgado Demera, H. El derecho a la igualdad de género en el ámbito educativo en el contexto de la pandemia COVID-19. Horiz. Rev. Investig. Rev. Investig. Cienc. Educ. 2021, 5, 462-470. [CrossRef]

16. Pulido-Montes, C.; Francia, G.; Ancheta-Arrabal, A. Biopolíticas de cierre de centros educativos desde una perspectiva de género: Los casos de España y Suecia. Rev. Española Educ. Comp. 2021, 38, 17-43. [CrossRef]

17. Vivanco-Saraguro, A. Teleducación en tiempos de COVID-19: Brechas de desigualdad. CienciAmérica 2020, 9, 166-175. [CrossRef]

18. Giroux, H.; Rivera-Vargas, P.; Passeron, E. Pedagogía Pandémica. Reproducción Funcional o Educación Antihegemónica. Rev. Rev. Int. Educ. Para Justicia Soc. 2020, 9, 1-7.

19. Reimers, F.M.; Schleicher, A. A Framework to Guide an Education Response to the COVID-19 Pandemic of 2020; OECD: Paris, France, 2020; Available online: https: / / read.oecd-ilibrary.org/view /?ref=126_126988-t63lxosohs\&title=A-framework-to-guidean-education-response-to-the-Covid-19-Pandemic-of-2020 (accessed on 6 June 2021). 
20. Van Dijk, T.A. The Deepening Divide: Inequality in the Information Society; SAGE Publications: London, UK, 2005.

21. Hilbert, M. Digital gender divide or technologically empowered women in developing countries? A typical case of lies, damned lies, and statistics. Women's Stud. Int. Forum 2011, 34, 479-489. [CrossRef]

22. Zubillaga, A.; Cortázar, L. Covid 19 y Educación I: Problemas, Respuestas y Escenarios. Documento Técnico de Análisis de la Situación Educativa Derivada de la Emergencia Sanitaria; Fundación COTEC: Madrid, Spain, 2020; Available online: https://cotec.es/cotecpublica-un-documento-con-propuestas-para-cinco-posibles-escenarios-educativos-ante-la-crisis-sanitaria-del-covid-19/ (accessed on 15 May 2021).

23. Basco, A.I.; Garnero, P. La brecha digital de género en América Latina. In Desafíos de la Administración Pública en el Contexto de la Revolución; Bellorno, S., Oszlak, O., Eds.; Konrad-Adenauer-Stiftung: Ciudad Autónoma de Buenos Aires, Argentina, 2020; pp. 119-150.

24. Gispert-Pellicer, E. La moda tecnológica en la educación: Los peligros de un espejismo. Pixel-Bit Rev. Medios Educ. 1997, 9, 81-92.

25. de la Selva, A.A.R. Los Nuevos Rostros de la Desigualdad en el Siglo XXI: La Brecha Digital. Rev. Mex. Cienc. Politicas Soc. 2015, 50, 265-285. [CrossRef]

26. UNESCO-IBI. Rapport Général De La Conférence Stratégies Et Politiques Informatiques Nationales; UNESCO: Paris, France, 1978.

27. Prensky, M. Homo sapiens digital: De los inmigrantes y nativos digitales a la sabiduría digital. In Conectados En El Ciberespacio; Aparici, R., Ed.; UNED: Madrid, España, 2010; pp. 93-106.

28. Pedró, F. New Millenium Learners in Higher Education: Evidence and Policy Implications; OECD: Paris, France, 2009.

29. ITU. ITU Internet Reports 2004: The Portable Internet; UIT Publications: Geneve, Switzerland, 2004; Available online: http: //handle.itu.int/11.1002/pub/800c7e3c-en (accessed on 1 November 2021).

30. Barrantes, R.; Vargas, E. Inequalities in the appropriation of digital spaces in metropolitan areas of Latin America. In Catalyzing Development through ICT Adoption the Developing World Experience; Ewa, H.K., Marszk, L.A., Eds.; SpringerLink: New York, NY, USA, 2016; pp. 207-226.

31. Galperin, H.; Arcidiacono, M. Employment and the gender digital divide in Latin America: A decomposition analysis. Telecommun. Policy 2021, 45, 102166. [CrossRef]

32. Pujol, J.; Montenegro, M. Technology and Feminism: A Strange Couple. Rev. Estud. Soc. 2015, 51, 173-185. [CrossRef]

33. Meneses-Cabrera, T.; Aranda-Bustamante, G. Sujeto-mujer y brecha digital de género. Discursos y prácticas desde lagubernamentalidad en América Latina. Signo Pensam. 2020, 39, 76.

34. Marín-Raventós, G.; Calderón-Campos, M. Typifying Mechanisms for Gender Digital Equity in Latin America. In ICT for Promoting Human Development and Protecting the Environment; Mata, F.J., Pont, A., Eds.; SpringerProfessional: New York, NY, USA, 2016; pp. 159-170.

35. Trucco, D. The Digital Divide in the Latin American context. In The Digital Divide the Internet and Social Inequality in International Perspective; Ragnedda, M., Muschert, G.W., Eds.; Routledge: New York, NY, USA, 2013; pp. 253-283.

36. González-Palencia, J.R.; Jiménez Fernández, C. La brecha de género en la educación tecnológica. Ens. Avaliação Políticas Públicas Educ. 2016, 24, 743-771.

37. UNESCO. UNESCO International Symposium and Policy Forum. Cracking the Code: Girls' Education in STEM; UNESCO: Paris, France, 2017; Available online: https:/ / en.unesco.org/unesco-international-symposium-and-policy-forum-cracking-code-girlseducation-stem (accessed on 10 September 2021).

38. Aydin, M. Does the digital divide matter? Factors and conditions that promote ICT literacy. Telemat. Inform. 2021, 58, 101536. [CrossRef]

39. Sánchez-Galvis, M. Implicaciones de Género en la Sociedad de la Información: Un Análisis desde los Determinantes de Uso de Internet en Chile y México. J. Technol. Manag. Innov. 2010, 5, 108-126. [CrossRef]

40. Botello-Peñaloza, H.A. Determinantes del acceso al internet: Evidencia de los hogares del Ecuador. Entramado 2015, 11, 12-19. [CrossRef]

41. Suárez, Y.M.; De Salvador, A.S.; De Salvador, G.X. Triplemente marcadas: Desconexiones comunicativas en la Amazonía sur ecuatoriana. Cuadernos.Info 2015, 36, 89-107. [CrossRef]

42. Martínez, Y. The Acquisition of Digital Capabilities as Means for Women's Development in Punto México Conectado. Theory Pract. Electron. Gonvernance 2016, 8, 412-415. [CrossRef]

43. Domínguez, J.G.; Alonso-Novelo, V.; Quiñonez Pech, S.H. Gender digital divide in Maya-speaking contexts of southern Mexico. RIDE Rev. Iberoam. Para Investig. Desarro. Educ. 2020, 11. [CrossRef]

44. Gray, T.J.; Gainous, J.; Wagner, K.W. Gender and the Digital Divide in Latin America. Soc. Sci. Quaterly 2017, 98, 326-340. [CrossRef]

45. Fraillon, J.; Ainley, J.; Schulz, W.; Duckworth, D.; Friedman, T. International Computer and Information Literacy Study 2018 Technical Report; International Association for the Evaluation of Educational Achievement: Amsterdam, The Netherlands, 2020.

46. Pérez-Escoda, A.; Lena-Acebo, F.J.; García-Ruiz, R. Brecha digital de género y competencia digital entre estudiantes universitarios. Aula Abierta 2021, 50, 505-5014. [CrossRef]

47. Vega, O.A. Medir la situación digital académica: Una acción de la gestión del conocimiento. E-Cienc. Inf. 2018, 8. [CrossRef]

48. Gigler, B.-S. Development as Freedom in a Digital Age: Experiences of the Rural Poor in Bolivia; World Bank Group: Washington, DC, USA, 2015. 
49. Montiel, A.V.; Zaigham, M.; Ibrahim, Y. Critical Issues on Gender Equality and ICTs in Latin America. In Politics, Protest, and Empowerment in Digital Spaces; Ibrahim, Y., Ed.; IGI Global Core: New York, NY, USA, 2017; pp. 263-275.

50. Delfino, G.; Sosa, F.; Zubieta, E. Uso de internet en Argentina: Género y edad cómo variables asociadas a la brecha digital. Investig. Desarro. 2017, 25, 100-123. [CrossRef]

51. Larghi, B.S. Desafíos de la inclusión digital en Argentina. Una mirada sobre el Programa Conectar Igualdad. Revista De Ciencias Sociales 2020, 33. [CrossRef]

52. Yansen, G.; Zukerfeld, M. Why Don't Women Program? Exploring Links between Gender, Technology and Software. Sci. Technol. Soc. 2014, 19, 305-329. [CrossRef]

53. Ruíz, P.A. Nuevas tecnologías y estudiantes chilenos de secundaria. Aportes a la discusión sobre la existencia de nuevos aprendices. Estud. Pedagógicos 2013, 39, 279-298. [CrossRef]

54. Gomez, C.S.; Vuorikari, R.; Punie, Y. DigComp 2.1: The Digital Competence Framework for Citizens with Eight Proficiency Levels and Examples of Use; Publications Office of the European Union: Luxembourg, 2017.

55. Agenda Digital Para América Latina Y El Caribe (eLAC2018), 2018. Available online: https://www.cepal.org/es/publicaciones/ 38886-agenda-digital-america-latina-caribe-elac2018 (accessed on 15 October 2021).

56. CEPAL. Agenda 2030 Y Los Objetivos De Desarrollo Sostenible Una Oportunidad Para América Latina Y El Caribe; CEPAL: Santiago de Chile, Chile, 2018.

57. Gutiérrez, I. Perfil del profesor universitario español en torno a las competencias en tecnologías de la información y la comunicación. Píxel-Bit Rev. Medios Educ. 2014, 44, 51-65. [CrossRef]

58. Plascencia, D.R. Educación a distancia y políticas públicas en materia de telecentros digitales: El caso del proyecto "CASA" de México. Cuadernos.Info 2014, 35, 55-67. [CrossRef]

59. González, A.V.; Contreras, V.L.; Monteverde, G.G. Viviendo con teléfono y pareja. Usos del celular en entornos de alta conectividad. Iztapalapa Rev. Cienc. Soc. Humanid. 2020, 89, 151-181. [CrossRef]

60. Dodel, M.; Aguirre, F. Digital inequalities' impact on progressive stages of e-government development. ACM Int. Conf. Proceeding Ser. 2018, 459-463. [CrossRef]

61. Fernández, M.; Vázquez, S. La Larga Y Compleja Marcha Del CLIP Al CLIC. Escuela Y Profesorado Ante El Nuevo Entorno Digital; Fundación Telefónica: Madrid, España, 2017.

62. Gracia Calandín, J. El desafío ético de la educación; Dykinson S.L.: Madrid, Spain, 2016.

63. Adell, J.; Castañeda, L. Tecnologías Emergentes, ¿pedagogías emergentes? In Educación y Tecnología; Hernández, J., Pennesi, M., Sobrino, D., Vázquez, A., Coords, Eds.; Tendencias emergentes en educación con TIC; Asociación Espiral: Bacerlona, España, 2012; pp. 13-32. Available online: https://digitum.um.es/jspui/bitstream/10201/29916/1/Adell_Castaneda_emergentes2012.pdf (accessed on 23 October 2021).

64. UNESCO. I'd Blush if I Could: Closing Gender Divides in Digital Skills through Education; UNESCO: Paris, France, 2019.

65. ECLAC-UNESCO. La Educación En Tiempos De La Pandemia COVID-19, 2020. Available online: athttps://unesdoc.unesco.org/ ark: / 48223/pf0000374075?posInSet=1\&queryId=9ccf4a39-7c50-43e4-856b-a09632daa7a2 (accessed on 23 October 2021).

66. Trucco, D.; Palma, A. Infancia Y Adolescencia En La Era Digital: Un Informe Comparativo De Los Estudiosdekids Online Del Brasil, Chile, Costa Rica Y El Uruguay; CEPAL: Santiago de Chile, Chile, 2020.

67. TomczyK, L.; Oyelere, S.S. ICT For Learning And Inclusion In Latin America And Europe. Case Study From Countries: Bolivia, Brazil, Cuba, Dominican Republic, Ecuador, Finland, Poland, Turkey And Uruguay; Pedagogical University of Cracow: Cracow, Poland, 2019. [CrossRef]

68. Tomczyk, L.; Costas, V.; Silveira, F.I.; Amado-Salvatierra, H.R.; Eliseo, M.A.; Sánchez, G.; Barros, M.J.; Oyelere, S.S. Digital Divide in Latin America and Europe: Main Caractheristics in selected countries. In Proceedings of the 14th Iberian Conference on Information Systems and Technologies (CISTI), Coimbra, Portugal, 19-22 June 2019; ISBN 978-989-98434-9-3.

69. Ancheta-Arrabal, A.; Carvajal-Mardones, V. Digitalización del sector educativo en América Latina: Estudio Comparado de la EdTech. In Desempeño, Docente y Formación en Competencia Digital en la Era SARS COV 2; Aznar-Díaz, I., López-Nuñez, J.A., Cáceres-Reche, M.P., De Barros-Camargo, C., Hijono-Lucena, F.J., Eds.; Dykinson S.L.: Madrid, Spain, 2021; pp. 296-310. ISBN 978-84-1377-304-9. 